\title{
The New Technologies and the Paradox of Global Consumption
}

\author{
Liton Lanes Pilau Sobrinho \\ University of Passo Fundo \\ University of Vale do Itajaí
}

The objective of this research is to analyze advertising as a means of mass communication which influences consumption patterns and affects social reality. The problem questions how advertising induces consumers in the midst of technological evolution. The methodology was developed through hypothetical-deductive method which is structured into three segments - mass media communication, advertising, and globalization and consumption. It is concluded that the media contributes to the construction of social reality and that there are many possibilities of consumption as it sells satisfaction, educates the consumer and ensures that information is important.

Keywords: consumption, mass communication, media, technology, advertising

\section{INTRODUCTION}

Communication is key in society. Mass media has the burden of spreading communication in the social media, promoting continuous descriptions of society and thus building social reality. Consequently, it becomes necessary to identify the communication elements in order to access the mass media.

Advertising can be understood as one of these elements, used mainly to catch and influence the attention of consumers, establishing new ideological patterns, which can drastically alter consumption patterns.

Therefore, it is important to analyze and rethink the ways of acting and thinking of today's society. Globalization and consumption operate a constant transformation of society, acting massively on individuals and generating an uncontrolled consumption, which for some people may not have good repercussions.

\section{MASS MEDIA COMMUNICATION}

To enter into the relationship of the importance of communication for the mass media, it is important to emphasize that the existence of communication is a possible condition for the existence of the mass media. However, it must be guided by circumstances to establish the initial notion about the communicative process. In order to understand its conceptualization "we resort, to explain it, to the metaphor of $<$ transmission $>$. It is stated that the communication transmits news or information from the sender to the receiver ${ }^{1 "}$. Therefore, in order for communication to occur, there is a sender and a receiver, with the one transmitting the information to the latter. 
It suggests that the sender transmits something that is received by the receiver. This is not the case, simply because the sender does not provide anything, in the sense that he/she loses something. The metaphor of possessing, having, giving and receiving does not help to understand communication. The transmission metaphor places the communication essentials in the act of communication. It focuses attention and skill requirements on the sender. The communication act, however, is only a selection proposal, a suggestion. Only when this suggestion is taken up again, when the stimulus is processed, is communication generated $^{2}$

Therefore, it means that the information analogy has a different meaning from the sender to the receiver, communication being a two-way path because this relationship goes through the transmission of information from the sender to the receiver. It is necessary to see the concept of meaning to clarify that communication is a process of choice. Luhmann states that:

Meaning only allows for selection. Communication takes something from the current reference horizon made up by itself, and leaves the other aside. Communication is the selection process. However, it does not choose how you take one thing and another from a deposit. [...]. The updated selection in the communication constitutes its own horizon, that which it already selects as selection, that is, as information. What it communicates is not only selected, but is already selected and therefore communicated. Therefore, communication should not be understood as a selective process of two, but of three selections. It is not only a question of sending and receiving with selective attention in each case; the selectivity of the information itself is a moment in the communicational process, because only in relation to it is selective attention activated. ${ }^{3}$

Through the meaning, communication cannot be understood as a process of two operations resulting from the sender and the receiver, because it goes beyond this understanding, being also linked to the different number of options before the information is communicated. Thus, the information selectivity process is a step in the communication process. With this conception is that Luhmann establishes the selections of the communication saying that,

[...] communication is a synthesis resulting from three selections: information, act of communication, understanding. Each of these components is, in itself, a contingent event. Information is a difference that transforms the state of a system, that is, it produces a difference." 4

It is notorious that the communication is done by the difference between information, act of communication and understanding, because it is very difficult that the communication reaches those who are present, in which they are the ones who manage to involve each other.

It can be stated that communication is an extremely unlikely event. The improbability of communication, however, can be overcome through the so-called symbolically widespread media. Such means act on a communicative chaos, making possible the communications success until then unlikely. Thus, the symbolically widespread means of communication are those

[...] means that use generalizations to symbolize the relationship between selection and motivation, that is, to represent it as a unit. Important examples are: truth, love, property/money, power/right; to some extent also religious faith, art and today, perhaps, civilized "core values". In a very different sense, and for very diverse interaction constellations, it is always a matter of conditioning the selection of communication in such a way that they act at the same time as motivating media, i.e., that they can sufficiently ensure compliance with the selection proposal. The most successful/transcendental 
communication takes place in today's society through such media and, consequently, the opportunities for the formation of social systems are directed towards their corresponding functions". 5

In this way, it can be identified that the communication is in the necessary synthesis so that the process of information transmission follows its receptors, and, through the act of communication, it may or may not ascend to its attendants. Thus, communication is essential for the mass media to enable transcendence of this same communication to those in audience. This makes it necessary to observe the media concept proposed by Luhmann

Under the concept of media must be understood, from now on, all society's institutions that use technical means of reproduction for the communication's diffusion. They are considered, mainly, books, magazines, newspapers produced in printed form, but also processes of photographic or electronic reproduction of any kind, to the point that they manufacture products in big quantity to an indeterminate public. Also the radio broadcasting is part of this concept as long as it is accessible to all and does not only serve to maintain the telephone connection between individual participants. The mass production of manuscripts based on the dictation, as occurred in medieval writing workshops, is not included in the concept, nor is public access to spaces where communication occurs - that is, the concept does not apply to conferences, theatrical performances, exhibitions, concerts, unless this dissemination takes place through films or floppy disks. ${ }^{6}$

Therefore, the media are not restricted to only one type. In this connection, it can be observed that the evolutionary process of the media takes place through the most diverse media, whether oral, written, sound, television and internet communication.

It is now necessary to consider the relationship between the reality of the media and the process of mass communication: "[...] we understand the institutions of society that use technologies of multiplication in order to disseminate communication. ${ }^{7}$ From this point of view, mass communication is an idea of extending the access to information by the most diverse media, such as television, radio, newspaper, etc. "In this definition, it is important to emphasize that there is no interaction between sender and receiver, the technology interposes itself between both. This disconnection guarantees the society's freedom of ${ }^{8}$ communication".

In the face of the media, its function becomes clear, ${ }^{9}$ which "[...] consists in the continuous production and processing of inconveniences and not in the increase of knowledge, nor in a socialization or education towards conformity to rules". ${ }^{10}$ Therefore, the media,

[...] guarantee to all function systems a presence that is accepted by all society and is at the same time familiar to individuals, a presence that they take as a starting point when it comes to selecting a specific past of the system, as well as fixing important future expectations for the system. Depending on individual needs, other systems can adapt their forecasts to past reference; the economy, for example, can adjust to innovations coming from firms or the market, and supported by this, set its own connections between its past and its future. ${ }^{11}$

Communication, therefore, is a condition of possibility for the existence of the media, because without communication there is no operation in the system. These exchanges are essential in order to adjust the future by identifying the past and thus reducing the complexity of frustration in reference to the past. It can be said that problems related to the complexity of public health, for example, undergo profound changes depending on the economy, because in the case of Brazil, without the Provisional Contribution on Financial Transactions (CPMF) there is not enough money for public health, linked to the crisis already faced in the past. In this way, it is important to verify the relationship and importance between advertising and mass media communication. 


\section{ADVERTISING}

Advertising plays a key role in the change of paradigms in postmodern society, as it can be a communication tool used most of the time to attract and influence people's interest in decision making. Thus, it can be understood as a fundamental link of social transformation and establishment of new customs of people who let themselves or not be influenced by it. Also,

[...] advertising may be motivated by the hope of achieving success in sales, but its latent function is to produce and consolidate criteria of good taste for those who lack it; that is, to provide security of judgment regarding the symbolic qualities of objects and behavioral patterns. [...] this latent function of advertising can then be used strategically to promote sales, but it also has an effect on those who do not buy anything. ${ }^{12}$

Thus, it can be observed that the advertising/propaganda doesn't have as main objective only to obtain success in sales, but it tries to establish standards of taste in people, the good or bad taste, trying to create a new behavior in the society to obtain success in sales. Mcluhann states

The continuous pressure is to create advertisements because there is more and more image of the reasons and wishes of the people. The importance of the product is inversely proportional to the increase in public participation. [...] the product and the public response become a single complex structure. [...] the strong trend in advertising is to declare the product as an integral part of great social processes and objectives [...] advertisements, therefore, tend to move away from the image that the consumer makes of the product, approaching the image of a producer's process. The so-called corporate image of the process includes the consumer in the role of producer, too. ${ }^{13}$

It is through this process of continuous repetition that advertising is carried out through the media and uses certain myths, that is, it uses prominent and renowned characters. As an example:" The matinee celebrities, movie stars, and idols are brought into the public domain [...]. They become dreams which can be bought with money; they can be bought, embraced and pointed out more easily than famous women." 14 When new consumption patterns are instituted, it leads to a wave of consumerism, determining the wishes of the public. To this is proposed an overwhelming fashion to achieve a certain social status, in case they consume the same product.

The complexity that involves advertising through its advertisements, conducts to establish persuasion patterns with a high level of noise by the constant repetition of advertisements, which create in people's unconscious new consumption patterns, is like brainwashing operated through the processes of advertising repetition. Luhmann states in his definition of the media

[...] it also works with two other genres, although not as exhaustively as journalism: advertising and entertainment. For him, advertising doesn't falsify anything, it actually places the cards on the table by declaring its motives and its intentions, despite hiding its means. The receiver is suggested freedom to decide whether or not to acquire the good or the service, but there is an "opacity", because, even playing openly, the paradoxical language of advertising is misleading: one can save by spending money, the article offered is exclusive, etc. Niklas Luhmann really thinks that advertising acts in a plan beyond market and consumption, working as a mechanism of balance between redundancy and variety, in which to buy the same product, the same brand, is rather an act of doubt than of confirmation; it is always necessary additional reasons, which is given by the production of illusion. This would be exactly the advertising dilemma, to always show something new and, at the same time, maintain brand loyalty: variety and redundancy. ${ }^{15}$ 
According to the author's proposal, advertising does not change anything, but it places the messages on the table, but hides its means, thus proposing to the receiver the condition of reducing complexity by the exercise of the purchase or not buying the products or services offered, established by the redundancy ${ }^{16}$ of buying the same product in function of the confidence of buying the same product.

Advertising, therefore, does not deal only with the economic issue; it also aims at sales success, which for media systems establishes a relationship between redundancy and variety, the first referring to what is sold and the second dealing with the possibility of people to distinguish products on the market. A new standard of advertising is instituted, which not only has the purpose of sales, but also to establish new standards through the repetitive process, placing in people's unconscious new standards in order to record the brands. Therefore,

advertising, therefore, does not act on immediate consumption, the exposure of the advantages or intrinsic values of goods (their "value of use"), but on substitute satisfaction: "buy a car and you will belong to an exclusive world, of special people", "for people like you, the Y whiskey", "for those who know what they want...", and so on. What you sell in advertising is by no means the product. This is absolutely secondary and is placed right on the edge, at the end, in a corner of the advertising. The ideological elements of capitalist world differentiation, which in the immediate reality do not find satisfaction, are much more sold. ${ }^{17}$

Through advertising, new ideological patterns of differentiation are established from the capitalist global village, the public's true satisfaction, a condition established by the economic influence on the media, with the intention of drastically altering consumption patterns. Thus, society often exchanges the usefulness of things for their redundancy, that is, for their superficiality, becoming directed by impulse, or letting itself be influenced by new behavioral patterns. For Marcondes Filho, the

[...] social differentiation proposed by capital is the distancing and artificial separation of individuals through the acquisition of goods with status. In the absence of a real situation for bourgeois living, with all its comforts and pleasures, the middle classes of capitalist societies are satisfied with their appearance. They simply display the symbolic objects of bourgeois life and lust. The ferocious struggle to own such goods takes place in all spaces of bourgeois socialization: at parties, in residences, in open activities, in malls, in supermarkets. Everywhere it is necessary that you "are on top", that you don't suffer with the crisis that you are superior, in short. ${ }^{18}$

Therefore, there is a new pattern established before the power of social differentiation proposed by capital, with new status paradigms for society, indicating a bourgeois experience, that is, of appearances and futilities, systematized through the symbols of bourgeois desires to be above others at all costs, regardless of crisis or not. We are faced with a paradigmatic rupture of social values, interposed by the influence of advertising, as a change in cultural patterns. Today, there is a new cycle of access to information by the most diverse media, having to put limits to the standards of economic power. We live a constant search for the rejuvenation patterns, result of the culture interposed by fashion, which imposes new standards of beauty to society, which often does not consider the health risks that these standards cause. The advertising uses these patterns to establish and promote the sale of beauty products and new surgical techniques, which acts in an aggressive way on the organism.

Therefore, with all the advances seen in communication it is difficult to establish the limits of their evolutionary processes. With this, advertising has a fundamental role in changing paradigms within society, since through it and the evolutionary process of communication it is possible to create new behavioral patterns in society. Given the importance of advertising, it is now time to verify its relationship with these new technologies and the paradox of globalization in consumer relations. 


\section{GLOBALIZATION AND CONSUMPTION}

Postmodern society is surrounded by the existence of paradoxes and contradictions. The constant presence of new technologies promotes a constant rethinking of ways of acting, thinking, etc., and also promotes a lot of possibilities not available until then. It is worth mentioning the emergence of new drugs, new forms of medical treatment, new equipment, etc.

These developments reflect the fact that "technique is the place of increased complexity and, therefore, increased possibilities". ${ }^{19}$ The countless possibilities brought by technologies increasingly complex social relations, bringing in themselves, in addition to chances of inclusion, excluding possibilities. The debate between the role/consequence of technologies for the individual is well referred to by Luhmann when he states that

The technique, then, in early modernity, is understood as an application of natural knowledge for human purposes, and even as an action parallel to divine creation or as a copy of archetypes foreseen in Creation. This made it possible to develop a science referred to under the name of "technology". Only this close link between nature and technique suggests the contrast - common today - between technique and humanity. [...] The warning is that man must not let his self-understanding be determined by technique; he must rebel against the dependencies that arise from it - just as he must rebel against domination without further ado; he must free himself from the alienation that technique and domination imply; he must "emancipate himself" - if he wants to save his humanity and selfdetermination". ${ }^{20}$

Technology, in this way, operates a constant transformation of society, acting massively on individuals, generating communications and thus building society with innovations and communicative possibilities hitherto unavailable. Regarding electronic media, Marcondes Filho explains Luhmannian understanding by stating that

Regarding electronic media, Luhmann expresses his concern when he says that computermediated communication can have a negative impact on social communication. It supposes that the computer could replace or overcome the constituent work of the communication society. The computer, when compared to what is defined in tradition about religion and art, modifies the relationship between surface (accessible) and depth. Since there is no space for a linear ordering that makes the meaning possible. ${ }^{21}$

These developments provide a chance to expand communication. The very use of computers translates the possibility of access to information by many recipients, temporally perpetuating its effects. Para Luhmann,

[...] this is also valid for both oral and written communication, the only difference being that the technology of diffusion of writing can make the event of communication reach temporarily and especially - many recipients, and thus make it occur at unpredictable moments. ${ }^{22}$

In this sense, technology can target new forms of human emancipation, seeking its meaning precisely in the possibility of exchanges that it constantly provides

The game of the Internet can help in the consolidation process of a society where the sense is to live in a compact way, to bet on the construction of another world through this one. The mechanism of the technique, also through the Internet, can represent a form of emancipation. ${ }^{23}$ 
Therefore, the Internet technology, which has been innovating every day, makes communication faster within society, however this cannot be generalized because although it can be recognized as a form of "emancipation", there are many individuals who still do not have the conditions for this access. This can be translated into the need of many to have access to certain goods and services and their consequent exclusion due to financial need.

Society has the means to promote public health, however, the voice of economic interests sometimes echoes louder. The technology, created with the purpose of solving problems, makes it impossible to include/exclude. Paradoxically, the very means designed to provide society with better control of its uncertainties make it trigger a massive exclusion process, where access to health technologies is given by a small portion of the population due to economic criteria.

The overcoming of exclusion can be made possible by the very communication operated by the mass media. The formation of a strong public opinion directed towards forms of inclusion and emancipation, promoted by the public (audience), is a condition of possibility for an increasingly self-political society, complexed to reduce complexity.

In view of this complexity, of access to new media with planetary action, society is faced with new conditions of possibilities of exploration in the process of globalization that

At the end of the 20th century and thanks to the advances of science, a system of techniques was produced based on information techniques, which began to play a role as a link between the others, connecting them and ensuring a planetary presence to the new technical system. But globalization is not only the existence of this new system of techniques. It is also the result of actions that ensure the emergence of a so-called global market, responsible for the most important political processes currently effective ${ }^{24}$.

In view of the globalization process, the formation of a universal market is seen, where there are no borders for capital and production is carried out in series, boosting the market that

Also the consumption changes over time. It was spoken before regarding the autonomy of the production, to indicate that a company, by ensuring a production, also sought to manipulate the opinion through advertising. In this case the generator fact of the consumption, would be the production. But, nowadays, hegemonic companies produce the consumer even before producing the products ${ }^{25}$.

We cannot become dependent on consumerism. Logically, this self-dependence created by the market brings, in the first instance, a convenience to people, but in the second instance, a self-dependence. When taking, for example, the Internet or even mobile telephony, we see that people are increasingly dependent on technology, which makes it possible to "travel" through the unknown. However,

[...] Any type of consumption considered typical of a specific period of human history can be presented without much effort as a slightly modified version of previous modalities. In this field, continuity appears to be the rule; ruptures, discontinuities, radical changes, not to mention revolutionary water divisor-type transformations, can be (and often are) rejected as merely quantitative rather than qualitative. ${ }^{26}$

The streams separator goes through a maturation process of the consumer market which needs, more and more, to respect the consumer which is the weakest link of this relationship, but a rupture will only be possible by consumer education, preserving the basic right of the Consumer Defense Code, which is the right to information. The radical change must take place when the market does not respect consumers, but there is a need for public opinion to pressure the state in order to intervene in the market and thus, in the near future, transform the social reality of the consumer market. 


\section{CONCLUSION}

The standards established by the communication constitute permanent descriptions of the system's state, pointing to later operations. In this way, the media operate in the sense of enabling constant indications from society, thus contributing to systemic permanent self-production and, jointly, to the construction of social reality, which will be guided by the observations and descriptions provided by the mass media.

Mass media provide reality descriptions, but at the same time they involve communications of uncertainties and risks. The difficulty of quantifying the power of communications, or the inability to measure its risks, promotes the indication of new communications to manage previous deficits, always bringing new reality descriptions.

The paradox established by the new conditions of possibility of media generates an autopoietic process of reproduction of information through virtual communities, on which it is not possible to have limits or controls, bringing consequences previously unimaginable in this universe of public space and allowing a new reality placed, with a diversified condition of communication possibility. From this systematic and one of the most important elements of mass media, which is advertising, it is important to analyze consumer relations.

As a result of these new technologies, the consumer goes crazy in the face of so many novelties and wants to be part of this new world. The market brings at all times novelties and conditions more accessible to the public and this is where the danger lies, because one can't forget that the consumer is the most fragile part in the consume relation. This is why adequate and accurate information is necessary so that conflicts do not occur in this area. This information can take place through consumer education and also through state intervention in the market, making public opinion fundamental for such effectiveness.

\section{ACKNOWLEDGEMENT}

Translated \& edited by American Publishing Services (https://americanpublishingservices.com/).

\section{ENDNOTES}

1. LUHMANN, Nilkas. Sistemas sociales: lineamentos para una teoría general. Barcelona/México/Santafé de Bogotá: Anthropos/Universidad Iberoamericana/CEJA. 1998. p. 141: “[...] se recurre, para explicarla, a la metáfora de la <información>. Se dice que la comunicación transmite noticias o información del emisor al receptor".

2. LUHMANN, Nilkas. Sistemas sociales: lineamentos para una teoría general. Barcelona/México/Santafé de Bogotá: Anthropos/Universidad Iberoamericana/CEJA. 1998. p. 141: "Sugiere que el emisor transmite algo que es recibido por El receptor. Este no es el caso, simplemente porque el emisor no da nada, en el sentido de que pierda él algo. La metafórica del poseer, tener, dar y recibir no sirve para comprender la comunicación. La métafora de la transmisión coloca lo esencial de la comunicación en el acto de la comunicación. Dirige la atención y los requerimientos de habilidad hacia el emisor. El acto de comunicar, sin embargo, no es más que una propuesta de selección, uns sugerencia. Sólo cuando se retoma esta sugerencia, cuando se processa el estímulo, se genera la comunicación."

3. LUHMANN, Nilkas. Sistemas sociales: lineamentos para una teoría general. Barcelona/México/Santafé de Bogotá: Anthropos/Universidad Iberoamericana/CEJA. 1998. p. 141: "El sentido no permite más que la selección. La comunicación toma algo del actual horizonte referencial constituido por ella misma, y deja aparte lo otro. La comunicación es el procesamiento de la selección. Sin embargo, no selecciona cómo se toma una y otra cosa de un depósito. [...] La selección actualizada en la comunicación constituye su proprio horizonte, aquello que selecciona ya como selección, es decir, como información. Lo que comunica no soló es seleccionado, si no que ya es selección y, por eso mismo, es comunicado. Por ello, la comunicación no se debe entender como proceso selectivo de dos, sino de tres selecciones. No sólo se trata de emisión y recepción con una atención selectiva en cada caso; la selectividad misma de la información es un momento del proceso comunicacional, porque únicamente en relación con ella activarse la atención selectiva."

4. LUHMANN, Niklas; DE GIORGI, Rafaelle. Teoría de la sociedad. México: Universidad de Guadalajara/Univesidad Iberoamericana/ITESO, 1993. p. 81: “[...] la comunicación es una síntesis que 
resulta de tres selecciones: información, acto de comunicación, comprensión. Cada uno de estos componentes es, en sí mismo, un evento contingente. La información es una diferencia que transforma el estado de un sistema, es decir, que produce una diferencia."

5. LUHMANN, Nilkas. Sistemas sociales: lineamentos para una teoría general. Barcelona/México/Santafé de Bogotá: Anthropos/Universidad Iberoamericana/CEJA. 1998. p. 159-160: "medios que utilizan generalizaciones para simbolizar la relación entre selección y motivación, es decir, para representarla como unidad. Ejemplos importantes son: verdad, amor, propiedad/dinero, poder/derecho; hasta cierto punto también fe religiosa, arte y actualmente, quizá, "valores básicos" civilizatoriamente estandarizados. De manera muy diferente, y para constelaciones de interacción muy diversas, se trata en todos los casos de condicionar la selección de la comunicación de tal manera que actúen el mismo tiempo como medios motivadores, es decir, que pueden asegurar de manera suficiente el cumplimiento de la propuesta de selección. La comunicación más exitosa/trascendental se realiza en la sociedad actual mediante tales medios de comunicación y, en consecuencia, las oportunidades para la formación de los sistemas sociales son dirigidos hacia sus funciones correspondientes."

6. LUHMANN, Niklas. A realidade dos meios de comunicação. São Paulo: Paulus, 2005. p. 16-17.

7. MARCONDES FILHO, Ciro. O escavador de silêncios: formas de construir e de desconstruir sentidos na comunicação: nova teoria da comunicação II. São Paulo: Paulus, 2004. p. 494.

8. MARCONDES FILHO, Ciro. O escavador de silêncios: formas de construir e de desconstruir sentidos na comunicação: nova teoria da comunicação II. São Paulo: Paulus, 2004. p. 494.

9. Nesse sentido, segundo WOLF, Mauro. Teorias das comunicações de massa. São Paulo: Martins Fontes, 2003. p. 55: "o inventário das funções correlaciona-se a quatro tipos de fenômenos de comunicação diversos: a. a existência do sistema global dos meios de comunicação de massa numa sociedade; b. os tipos de modelos específicos de comunicação ligados a cada meio particular (imprensa, rádio, etc); c. a ordem institucional e organizacional com que os diversos meios de comunicação operam; d. as conseqüência do fato de as principais atividades de comunicação se desenvolverem por intermédio dos meios de comunicação de massa."

10. LUHMANN, Niklas. A realidade dos meios de comunicação. São Paulo: Paulus, 2005. p. 159.

11. LUHMANN, Niklas. A realidade dos meios de comunicação. São Paulo: Paulus, 2005. p. 160-161.

12. LUHMANN. Niklas. La sociedad de la sociedad. México: Herder Editorial/Universidad Iberoamericana, 2007. p. 875: "La publicidad puede estar motivada por la esperanza de alcanzar éxito en las ventas, pero su función latente está en producir y consolidar criterios del buen gusto para aquellas personas que carecen de él; es decir, surtir de seguridad de juicio respecto a las cualidades simbólicas de objetos y modos de conducta. $[\ldots]$ esta función latente de la publicidad puede luego aprovecharse estratégicamente para fomentar de este modo las ventas, aunque surte también sus efectos en quienes nada compran."

13. MCLUHAN, Herbert Marshall. Os meios de comunicação como extensões do homem. Tradução Décio Pignatari. São Paulo: Cultrix, 2003. p. 255.

14. MCLUHAN, Herbert Marshall. Os meios de comunicação como extensões do homem. São Paulo: Cultrix, 2003. p. 215.

15. MARCONDES FILHO, Ciro. O escavador de silêncios: formas de construir e de desconstruir sentidos na comunicação: nova teoria da comunicação II. São Paulo: Paulus, 2004. p. 500.

16. Para LUHMANN, Niklas. Ecological Communication. Chicago: University of Chicago Press, 1989. p.145. Redundância As múltiplas certificações de funções, por esta razão parecem supérfluas. A rejeição da redundância enquanto mecanismos multifuncionais devem substituir por funcionalidades específicas que serão aplicadas para (autopoiética) auto-certificação. (minha tradução). Redundancy The multiple certification of a function, therefore the appearance of 'superfluit'. The rejection of redundancy means that multifunctional mechanisms have to be replaced by functionally specif ones that are applied to (autopoietic) self-certification.

17. MARCONDES FILHO, Ciro. Quem manipula quem? Poder e massas na indústria da cultura e da comunicação no Brasil. 5. ed. Petrópolis: Vozes, 1992, p. 145.

18. MARCONDES FILHO, Ciro. Quem manipula quem? Poder e massas na indústria da cultura e da comunicação no Brasil. 5. ed. Petrópolis: Vozes, 1992, p. 123.

19. VIAL, Sandra Regina Martini. Sociedade complexa e o direito fraterno. In: SANTOS, André Leonardo Copetti; STRECK, Lênio Luiz; ROCHA, Leonel Severo (Org.). Constituição, sistemas sociais e hermenêutica: programa de pós-graduação em direito da UNISINOS: mestrado e doutorado. n. 3. Porto Alegre: Livraria do Advogado; São Leopoldo: UNISINOS, 2007. p. 183. 
20. LUHMANN, Niklas. La sociedad de la sociedad. México: Herder Editorial/Universidad Iberoamericana, 2007. p. 411-412: "La técnica, pues, en la modernidad temprana, se entiende como aplicación del saber natural para fines humanos, y hasta como acción paralela a la creación divina o como copia de arquetipos previstos en la Creación. Esto hizo posible concebir una ciencia referida a ello bajo el nombre de "tecnología". Sólo este nexo estrecho entre naturaleza y técnica sugiere el contraste - hoy común - entre técnica y humanidad. [...] La advertencia es que el ser humano no debe dejar que su autocomprensión se determine por la técnica; debe rebelarse contra las dependencias que de allí emanan - así como debe rebelarse contra la dominación sin más; debe liberarse de la enajenación que implica la técnica y la dominación; debe "emanciparse" - si es que quiere salvar su humanidad y su autodeterminación"

21. MARCONDES FILHO, Ciro. O escavador de silêncios: formas de construir e de desconstruir sentidos na comunicação: nova teoria da comunicação II. São Paulo: Paulus, 2004. p. 464.

22. LUHMANN, Niklas. La sociedad de la sociedad. México: Herder Editorial/Universidad Iberoamericana, 2007. p. 49.

23. VIAL, Sandra Regina Martini. Sociedade complexa e o direito fraterno. In: SANTOS, André Leonardo Copetti; STRECK, Lênio Luiz; ROCHA, Leonel Severo (Org.). Constituição, sistemas sociais e hermenêutica: programa de pós-graduação em direito da UNISINOS: mestrado e doutorado. n. 3. Porto Alegre: Livraria do Advogado; São Leopoldo: UNISINOS, 2007. p. 186.

24. SANTOS, Milton. Por uma outra globalização: do pensamento único à consciência universal. $18^{\mathrm{a}}$ Ed. Rio de Janeiro: Record, 2009. P. 23-24.

25. SANTOS, Milton. Por uma outra globalização: do pensamento único à consciência universal. $18^{\mathrm{a}}$ Ed. Rio de Janeiro: Record, 2009. P. 48.

26. BAUMAN, Zygmunt. Vida para consumo: a transformação das pessoas em mercadorias; tradução Carlos Alberto Medeiros. Rio de Janeiro: Jorge Zahar Ed., 2008. P. 37-38.

\section{REFERENCES}

Bauman, Z. (2008). Vida para consumo: A transformação das pessoas em mercadorias. Tradução Carlos Alberto Medeiros. Rio de Janeiro: Jorge Zahar Ed.

Luhmann, N. (1989). Ecological Communication. Chicago: University of Chicago Press.

Luhmann, N. (2005). A realidade dos meios de comunicação. São Paulo: Paulus.

Luhmann, N. (2007). La sociedad de la sociedad. México: Herder Editorial/Universidad Iberoamericana.

Luhmann, N. (1998). Sistemas sociales: Lineamentos para una teoría general. Barcelona/México/Santafé de Bogotá: Anthropos/Universidad Iberoamericana/CEJA.

Luhmann, N., \& De Giorgi, R. (1993). Teoría de la sociedad. México: Universidad de Guadalajara/ Univesidad Iberoamericana/ITESO.

Marcondes Filho, C. (1992). Quem manipula quem? Poder e massas na indústria da cultura e da comunicação no Brasil (5th ed). Petrópolis: Vozes.

Marcondes Filho, C. (2004). O escavador de silêncios: Formas de construir e de desconstruir sentidos na comunicação. Nova teoria da comunicação II. São Paulo: Paulus.

Mcluhan, H.M. (2003). Os meios de comunicação como extensões do homem. Tradução Décio Pignatari. São Paulo: Cultrix.

Santos, M. (2009). Por uma outra globalização: Do pensamento único à consciência universal (18 ${ }^{\mathrm{a}}$ Ed.). Rio de Janeiro: Record.

Staffen, M.R. (2019, December 30). Global Normative Production for the Tutelage of Sustainability. Journal of Applied Business and Economics, 21(8).

Vial, S.R.M. (2007). Sociedade complexa e o direito fraterno. In A.L.C. Santos, L.L. Streck, \& L.S. Rocha (Org.), Constituição, sistemas sociais e hermenêutica: Programa de pós-graduação em direito da UNISINOS: Mestrado e doutorado (No.3). Porto Alegre: Livraria do Advogado; São Leopoldo: UNISINOS.

Wolf, M. (2003). Teorias das comunicações de massa. São Paulo: Martins Fontes. 